\title{
INVESTIGATION OF EARLY COMPRESSIVE STRENGTH OF FLY ASH-BASED GEOPOLYMER CONCRETE
}

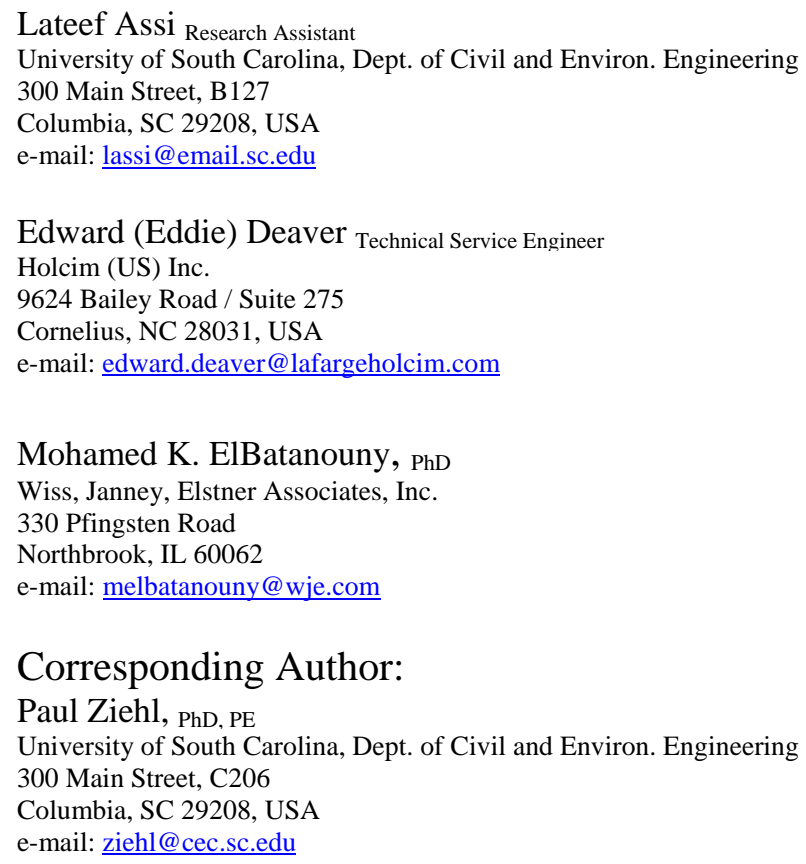


BASED GEOPOLYMER CONCRETE

\section{Abstract}

Development of sustainable construction materials has been the focus of research efforts

32 worldwide in recent years. Concrete is a major construction material; hence, finding alternatives

33 to ordinary Portland cement is of extreme importance due to high levels of carbon dioxide

34 emissions associated with its manufacturing process. This study investigates the effects of

35 activating solution type, curing procedure, and source of fly ash in relation to the resulting

36 compressive strength of fly ash-based geopolymer concrete. The fly ash-based geopolymer paste

37 microstructure was observed and density, absorption and voids were measured. Two activating

38 solutions were used: a) a mixture of sodium hydroxide, silica fume, and water; and b) a mixture

39 of sodium hydroxide solution, sodium silicate, and water. Test results indicate that the resulting

40 concrete has the potential for high compressive strength and the compressive strength is directly

41 affected by the source of fly ash. Results further indicate that compressive strength is not

42 significantly affected by the curing condition when silica fume is used in the activating solution

43 in comparison to the use of sodium silicate.

44 Keywords: alkali-activated fly ash concrete, geopolymer concrete, early compressive strength,

45 silica fume activating solution, sodium silicate activating solution

\footnotetext{
${ }^{1}$ FGC = Fly ash-based Geopolymer concrete

${ }^{2}$ FGC-silica fume $=$ FGC with silica fume in the activating solution

${ }^{3}$ FGC-sodium silicate $=$ FGC with sodium silicate in the activating solution

${ }^{4} \mathrm{SEM}=$ Scanning Electron Microscopy
} 


\section{Introduction}

A significant amount of concrete is used in construction around the world and Portland cement is one of the main constituents. Due to the very high temperatures required for the

51 manufacture of Portland cement, vast amounts of energy are utilized for this ubiquitous

52 construction material. It has been stated that the production of each ton of Portland cement

53 releases approximately one ton of carbon dioxide [1], and that Portland cement industries

54 contribute $5 \%$ to $7 \%$ of total worldwide $\mathrm{CO}_{2}$ emissions [2]. In recent decades, a sustainable

55 development has become a focus of scientists and engineers and, therefore, the quest for 56 alternatives to this technology has accelerated.

57 One potential alternative to Portland cement based concrete is fly ash-based geopolymer 58 concrete (FGC), which may have the potential to reduce Portland cement usage while mirroring 59 the compressive strength and durability characteristics of Portland cement concrete [3,4]. Many 60 studies have shown that FGC can demonstrate beneficial and diverse properties. For example,

61 FGC has shown good resistance against acid and sulfate attack, high early age strength, and good

62 performance in high temperatures [5-12]. It has been proven recently that FGC can achieve high

63 early and final compressive strength in ambient curing condition, and good workability when

64 additives are incorporated such as Portland cement, calcium hydroxide, or ground granulated

65 blast furnace slag [13]. FGC is an inorganic polymer, which is produced by the reaction of 66 alumino-silicate materials with alkaline solutions and the addition of conventional coarse and

67 fine aggregate. FGC makes use of fly ash, which is a good source of alumino-silicate and is also

68 a prevalent waste material. While the study described is focused on the use of fly ash, other 69 waste materials such as blast furnace slag may also be utilized [14, 15]. FGC is generally agreed 
70 to be less deleterious to the environment than Portland cement based concrete; however, more

71 work to quantify this assertion is warranted.

72 A significant number of research studies have been conducted on FGC wherein sodium

73 silicate was utilized in the activating solution $[16,17,18,19]$, as is also the case for alkali

74 activated slag [20, 21]. In contrast, relatively few studies have investigated the combination of

75 silica fume and sodium hydroxide as the activating solution [22]. Issues noted with the use of

76 sodium silicate in the activating solution include relatively low workability and lower

77 compressive strength when compared to conventional Portland cement based concrete,

78 considered as $21 \mathrm{MPa}$ (3,000 psi) to $41 \mathrm{MPa}(6,000 \mathrm{psi})$. Both activating solutions have the same

79 major chemical components including $\mathrm{Na}_{2} \mathrm{O}$, and $\mathrm{SiO}_{2}$. However, the main differences are: 1)

80 process of manufacturing, for instance sodium silicate solution is subjected to high temperature

81 between $1100^{\circ} \mathrm{C}$ and $1200^{\circ} \mathrm{C}\left(2012^{\circ} \mathrm{F}\right.$ and $\left.2192^{\circ} \mathrm{F}\right)$, and then subjected to high pressure, and 2$)$

82 the ratio of $\mathrm{Si} / \mathrm{Na}$ in the activating solution where the ratio is higher in the silica fume based

83 solution than the sodium silicate based solution. The strength of FGC has been noted to be

84 improved when external heat in the range of $75^{\circ} \mathrm{C}\left(167^{\circ} \mathrm{F}\right)$ was applied early in the curing

85 process. It is mentioned that the application of some external heat early in the curing process is

86 feasible and relatively common for precast/prestressed concrete applications.

87 In addition to the materials utilized in the activating solution, the chemical composition

88 of the fly ash itself varies considerably depending on the coal source and technological processes

89 used, and these factors may significantly affect the resulting FGC properties [23]. Comparisons

90 between different activating solutions and sources of fly ash are not widely available. This study

91 aims to address some of the current gaps in knowledge by investigating the effects of activating 
92 solution type, curing procedure, and source of fly ash in relation to the resulting compressive 93 strength of FGC.

94 This paper compares compressive strength results obtained for FGC using either sodium

95 silicate or silica fume in the activating solution. One significant finding is that the use of silica

96 fume in the activating solution increases the compressive strength in comparison to the use of

97 sodium silicate in the activating solution, potentially due to the higher silica concentration and 98 smaller particle size of silica fume. The effect of different fly ash sources and curing conditions

99 (samples stored either inside or outside the molds till the test day) are also investigated. The

100 results indicate that the fly ash source has a significant effect on the resulting compressive

101 strength. To gain further insight, the microstructure was observed to identify the major

102 differences between fly ash sources by Scanning Electron Microscopy (SEM). To address and 103 gain a better understanding of potential durability considerations, density, absorption and voids

104 were measured in general conformance with ASTM (C 642-06) [24].

\section{2. Materials and methods}

106 In this section two experiments have been chosen from previous studies as first step. For

107 FGC-silica fume, the mixture proportions followed Tempest et al. 2009 [22]. FGC-sodium

108 silicate mixture proportions followed Lloyd and Rangan 2010 [18] due to high compressive

109 strength and moderate workability. However, the mixture proportions were slightly changed to 110 improve the compressive strength.

111 The materials used for fabrication of the FGC test specimens included fly ash (ASTM

112 class F), activating solution (either sodium hydroxide mixed with silica fume or sodium

113 hydroxide solution mixed with sodium silicate solution), and fine aggregate, water, and super

114 plasticizer (Sika ViscoCrete 2100). Two fly ash sources were utilized in the investigation: a) 
115 Belews Creek, from a power station in North Carolina, and b) Wateree Station, from a power

116 station in South Carolina. The Wateree Station fly ash source was processed differently from the

117 Belews Creek source, in that the Wateree Station source was subjected to a proprietary carbon

118 burn out process. Chemical compositions of both fly ash sources are shown in Table 1 . The

119 activating solution used was either: a) silica fume (Sikacrete 950DP, densified powder silica

120 fume), sodium hydroxide (97-98 purity, DudaDiesel), and water; or b) sodium silicate solution

$121\left(\mathrm{NaO}_{2}=14.7 \%, \mathrm{SiO}_{2}=29.4 \%\right.$, and water $=55.9 \%$, PQ Corporation $)$, sodium hydroxide solution

122 (14 M), and water. Local crushed coarse granite aggregates (Vulcan Materials) in a saturated

123 surface dry condition and local fine aggregates (Glasscock) were used. The gradation of coarse

124 and fine aggregate is provided in Table 2, and the proportions of the silica fume and sodium

125 silicate based FGC are provided in Table 3.

126 X-ray Florence (XRF) and Thermal Gravimetric Analysis (TGA) were conducted to 127 investigate the effect of fly ash source materials on FGC-silica fume at the Holcim (US), Inc.

128 laboratory in Holly Hill, South Carolina. SEM observations were conducted on fly ash-based 129 geopolymer silica fume paste samples in the SEM Center at University of South Carolina.

130 Density, absorption and voids for FGC (silica fume and sodium silicate based) were measured 131 according to ASTM (C 642-06) at 7 days after casting. 
Table 1: XRF chemical analysis of fly ash

\begin{tabular}{|l|c|c|}
\hline Chemical analysis & Belews Creek Station, wt.\% & Wateree Station wt.\% \\
\hline Silicon Dioxide & 50.2 & 53.5 \\
\hline Aluminum Oxide & 26.4 & 28.8 \\
\hline Iron Oxide & 10.0 & 7.5 \\
\hline Sum of Silicon Dioxide, Aluminum Oxide & 86.41 & 89.8 \\
\hline Calcium Oxide & 4.3 & 1.6 \\
\hline Magnesium Oxide & 1.3 & 0.8 \\
\hline Sulfur Trioxide & 0.9 & 0.1 \\
\hline Loss on Ignition & 2.0 & 3.1 \\
\hline Moisture Content & 0.1 & 0.1 \\
\hline Total Chlorides & $<0.002$ & ------ \\
\hline Available Alkalies as $\mathrm{NaO}_{2}$ & 0.7 & 0.8 \\
\hline
\end{tabular}

134

Table 2: Gradation of coarse and fine aggregate

\begin{tabular}{|c|c|c|}
\hline Sieve $(\mathrm{mm})$ & Coarse aggregate \% passing & Fine aggregate \% passing \\
\hline 16.0 & 100.0 & 100.0 \\
\hline 12.5 & 99.5 & 100.0 \\
\hline 9.50 & 85.3 & 99.8 \\
\hline 4.75 & 28.8 & 99.5 \\
\hline 2.36 & 5.5 & 97.9 \\
\hline 1.18 & 1.3 & 90.4 \\
\hline 0.43 & 0.7 & 37.2 \\
\hline 0.30 & 0.7 & 20.0 \\
\hline 0.15 & 0.5 & 1.6 \\
\hline Pan & 0.0 & 0.0 \\
\hline
\end{tabular}

136 
Table 3: Mixture proportions

\begin{tabular}{|c|c|c|c|c|c|c|c|c|c|}
\hline $\begin{array}{l}\text { Concrete } \\
\text { type }\end{array}$ & $\begin{array}{c}\text { Fly } \\
\text { ash, } \\
\mathrm{kg} / \mathrm{m}^{3} \\
\left(\mathrm{lb} / \mathrm{ft}^{3}\right)\end{array}$ & $\begin{array}{l}\text { Water, } \\
\mathrm{kg} / \mathrm{m}^{3} \\
\left(\mathrm{lb} / \mathrm{ft}^{3}\right)\end{array}$ & $\begin{array}{l}\mathrm{w} / \mathrm{b} \\
\text { ratio }\end{array}$ & $\begin{array}{c}\text { Sodium } \\
\text { hydroxide, } \\
\mathrm{kg} / \mathrm{m}^{3} \\
\left(\mathrm{lb} / \mathrm{ft}^{3}\right)\end{array}$ & $\begin{array}{l}\text { Silica } \\
\text { fume, } \\
\mathrm{kg} / \mathrm{m}^{3} \\
\left(\mathrm{lb} / \mathrm{ft}^{3}\right)\end{array}$ & $\begin{array}{l}\text { Sodium } \\
\text { silicate, } \\
\mathrm{kg} / \mathrm{m}^{3} \\
\left(\mathrm{lb} / \mathrm{ft}^{3}\right)\end{array}$ & $\begin{array}{l}\text { Coarse } \\
\text { agg., } \\
\mathrm{kg} / \mathrm{m}^{3} \\
\left(\mathrm{lb} / \mathrm{ft}^{3}\right)\end{array}$ & $\begin{array}{c}\text { Fine } \\
\text { agg., } \\
\mathrm{kg} / \mathrm{m}^{3} \\
\left(\mathrm{lb} / \mathrm{ft}^{3}\right)\end{array}$ & $\begin{array}{c}\text { SP\% } \\
\text { of fly } \\
\text { ash }\end{array}$ \\
\hline $\begin{array}{l}\text { Mix 1: } \\
\text { silica fume } \\
\text { based } \\
\text { activating } \\
\text { solution }\end{array}$ & $\begin{array}{c}474 \\
(29.6)\end{array}$ & $\begin{array}{c}163 \\
(10.2)\end{array}$ & 0.28 & $\begin{array}{l}61.6 \\
(3.8)\end{array}$ & $\begin{array}{c}2.9 \\
(46.2)\end{array}$ & - & $\begin{array}{c}793 \\
(49.5)\end{array}$ & $\begin{array}{c}793 \\
(49.5)\end{array}$ & 1.5 \\
\hline $\begin{array}{c}\text { Mix 2: } \\
\text { sodium } \\
\text { silicate } \\
\text { activating } \\
\text { solution }^{*}\end{array}$ & $\begin{array}{c}408 \\
(25.5)\end{array}$ & & 0.22 & $\begin{array}{c}41 \\
(2.6)\end{array}$ & - & $\begin{array}{c}6.4 \\
(103)\end{array}$ & $\begin{array}{c}1110 \\
(69.2)\end{array}$ & $\begin{array}{c}739 \\
(46.1)\end{array}$ & 1.5 \\
\hline $\begin{array}{c}\text { Mix 3: } \\
\text { sodium } \\
\text { silicate } \\
\text { activating } \\
\text { solution }\end{array}$ & $\begin{array}{c}408 \\
(25.5)\end{array}$ & $\begin{array}{l}22.5 \\
(1.4)\end{array}$ & 0.22 & $\begin{array}{c}41 \\
(2.6)\end{array}$ & - & $\begin{array}{c}6.4 \\
(103)\end{array}$ & $\begin{array}{l}922.7 \\
(57.6)\end{array}$ & $\begin{array}{l}922.7 \\
(57.6)\end{array}$ & 1.5 \\
\hline
\end{tabular}

*Mix 2 is used in all the compressive strength results other than SS-W-OM-3

For the silica fume based activating solution, sodium hydroxide flakes were dissolved in

142 water and silica fume powder was then added and stirred for two minutes. The mixing of silica

143 fume with sodium hydroxide and water resulted in an exothermic process (in excess of $80^{\circ} \mathrm{C}$

$\left.144\left[176^{\circ} \mathrm{F}\right]\right)$. The activating solution was kept in a closed container in an oven at $75^{\circ} \mathrm{C}\left(167^{\circ} \mathrm{F}\right)$ for

14512 hours to assure that the sodium hydroxide flakes and silica fume powder were completely

146 dissolved. The water/binder ratio (w/b) was calculated as $28 \%$. This ratio was calculated by

147 dividing the water weight over summation of dried fly ash, sodium hydroxide and silica fume

148 weight.

149 For the sodium silicate based activating solution, the sodium hydroxide solution (14

150 molarity concentration) was prepared by dissolving sodium hydroxide flakes in water and kept

151 for at least 24 hours in ambient conditions. The sodium hydroxide and sodium silicate solution

152 were then mixed together. The resulting solution was stored at ambient temperature for a period 
153 of at least 24 hours, and then the extra water was added prior to mixing of activating solution

154 with the dry ingredients (fly ash, fine aggregates, and coarse aggregates). Therefore, the 155 water/binder (w/b) ratio of $22 \%$ was calculated by dividing total water weight ( $55.9 \%$ of weight

156 of sodium silicate, the water of sodium hydroxide solution, and the extra water [22.5 kg/m ${ }^{3}(1.4$

$157 \mathrm{lb} / \mathrm{ft}^{3}$ )]) by weight of fly ash, sodium hydroxide flakes, $14.7 \%$ of sodium silicate for $\mathrm{NaO}_{2}$, and

$15829.4 \%$ of sodium silicate for $\mathrm{SiO}_{2}$ weight. It is worth noting that using higher w/b for FGC-

159 sodium silicate will reduce the compressive strength drastically.

160 Mixing sodium silicate and sodium hydroxide solution does not result in significant

161 exothermic heat. Since both sodium silicate and sodium hydroxide are in liquid state, external

162 heat was not required for solution preparation, unlike the silica fume based activating solution

163 described above.

\subsection{Casting and curing}

The dry ingredients (fly ash, fine aggregates, and coarse aggregates) were mixed for three

166 minutes. The activating solution, which include the water, was then added to the dry mixture and

167 mixed for five minutes. Cylinders with dimensions of $76 \mathrm{~mm}$ x $152 \mathrm{~mm}$ (3 in. x 6 in.) were cast

168 by adding three lifts of concrete and rodding 60 times per lift with a $9.5 \mathrm{~mm}(0.3 \mathrm{in}$.) diameter

169 rod [8]. The size of cylinders was chosen according to ACI 211.1-91 [20]. All specimens were

170 externally vibrated for a period of 10 seconds [8]. For FGC-silica fume, the specimens were left

171 in ambient condition for two days and then heated for a period of two days in an oven at $75{ }^{\circ} \mathrm{C}$

$172\left(167^{\circ} \mathrm{F}\right)$ [17]. For FGC-sodium silicate, the specimens were left for one day in ambient

173 conditions and were then heated for a period of two days in the same oven at $75^{\circ} \mathrm{C}\left(167^{\circ} \mathrm{F}\right)$. The

174 difference in aging time prior to placing in the oven is reported, but is not believed to be

175 significant. Compressive strength testing was conducted at seven days after casting in all cases. 
A total of forty FGC cylinders were mixed, cast, and conditioned. To enable the 177 calculation of standard deviation four specimens of each type were prepared. One factor was 178 altered while other factors were held constant [26]. The specimen nomenclate is described in the

179 footnote to Table 4. Three variables were investigated: a) type of activating solution (either silica 180 fume/sodium hydroxide/water or sodium silicate/sodium hydroxide/water); referred to as either 181 'silica fume' or 'sodium silicate' based activating solutions, SF or SS; b) source of fly ash 182 (Belews Creek or Wateree Station), B or W; and c) curing condition (cured inside the plastic 183 cylinder molds or cured outside the plastic cylinder molds, with mold removal performed just 184 after the specimens were taken out of the oven), IM or OM. For example, SF-W-IM-1 indicates 185 silica fume based activating solution, Wateree Station fly ash, cured inside the molds, patch 186 number 1 of this type.

187 The test matrix contained two different sets of replicates as follows: a) silica fume based 188 activating solution/Wateree Station fly ash/cured inside the molds (SF-W-IM), and b) sodium 189 silicate based activating solution/Wateree Station fly ash/cured outside the molds (SS-W-OM). 190 Replicate mixes are delineated with gray shading in Table 4. For the Wateree Station fly ash 191 source, all variables of activating solution type and curing condition were thoroughly 192 investigated. For the Belews Creek fly ash source, two combinations were studied (SF-B-IM and 193 SS-B-OM). 
Table 4: Matrix of test specimens

\begin{tabular}{|c|c|c|c|c|c|c|c|}
\hline & \multicolumn{2}{|c|}{ Activating solution } & \multicolumn{2}{|c|}{ Fly ash source* } & \multicolumn{2}{|c|}{ Curing condition } & \multirow[b]{2}{*}{$\begin{array}{l}\text { Number of } \\
\text { specimens }\end{array}$} \\
\hline $\begin{array}{l}\text { Specimen } \\
\text { type }\end{array}$ & $\begin{array}{l}\text { Silica } \\
\text { fume }\end{array}$ & $\begin{array}{l}\text { Sodium } \\
\text { silicate }\end{array}$ & $\begin{array}{l}\text { Wateree } \\
\text { Station }\end{array}$ & $\begin{array}{c}\text { Belews } \\
\text { Creek }\end{array}$ & $\begin{array}{l}\text { Inside the } \\
\text { molds }\end{array}$ & $\begin{array}{c}\text { Outside the } \\
\text { molds }\end{array}$ & \\
\hline $\begin{array}{c}\text { SF-W-IM } \\
1\end{array}$ & X & & X & & $\mathrm{X}$ & & 4 \\
\hline SF-W-IM-2 & $\mathrm{X}$ & & $\mathrm{X}$ & & $\mathrm{X}$ & & 4 \\
\hline SF-W-IM-3 & $\mathrm{X}$ & & $\mathrm{X}$ & & $\mathrm{X}$ & & 4 \\
\hline SF-W-OM ${ }^{6}$ & $\mathrm{X}$ & & $\mathrm{X}$ & & & $\mathrm{X}$ & 4 \\
\hline $\begin{array}{c}\text { SS-W-OM }{ }^{7}- \\
1\end{array}$ & & $X$ & X & & & $\mathrm{X}$ & 4 \\
\hline $\begin{array}{c}\text { SS-W-OM- } \\
2\end{array}$ & & $\mathrm{X}$ & $\mathrm{X}$ & & & $\mathrm{X}$ & 4 \\
\hline $\begin{array}{c}\text { SS-W-OM- } \\
3^{* *}\end{array}$ & & $\mathrm{X}$ & $\mathrm{X}$ & & & $\mathrm{X}$ & 4 \\
\hline SF-B-IM ${ }^{8}$ & $\mathrm{X}$ & & & $\mathrm{X}$ & $\mathrm{X}$ & & 4 \\
\hline $\begin{array}{c}\text { SS-W-IM }{ }^{9}- \\
1\end{array}$ & & $\mathrm{X}$ & $\mathrm{X}$ & & $\mathrm{X}$ & & 4 \\
\hline SS-B-OM ${ }^{10}$ & & $\mathrm{X}$ & & $\mathrm{X}$ & & $X$ & 4 \\
\hline $\begin{array}{l}\text { *both } \\
\text { **Mi } \\
\text { Note: } \\
\text { Note: } \\
\mathrm{SF}=\mathrm{s} \\
\mathrm{SS}=\mathrm{s} \\
\mathrm{W}=\mathrm{Y} \\
\mathrm{B}=\mathrm{B} \\
\mathrm{IM}=\mathrm{c} \\
\mathrm{OM}=\end{array}$ & $\begin{array}{l}\text { ly ash sol } \\
\text { ure No. } 3 \\
\text { haded ce } \\
\text { haded ce } \\
\text { ica fume } \\
\text { dium sili } \\
\text { ateree fly } \\
\text { ews Cree } \\
\text { red insid } \\
\text { ured outs }\end{array}$ & $\begin{array}{l}\text { s Type F } \\
\text { able 3) } \\
\text { ndicate replic } \\
\text { ndicate replic } \\
\text { ed activating } \\
\text { based activat } \\
\text { y ash } \\
\text { e molds } \\
\text { the molds }\end{array}$ & $\begin{array}{l}\text { e specimens } \\
\text { e specimens } \\
\text { lution } \\
\text { g solution }\end{array}$ & & & & \\
\hline
\end{tabular}

\section{Results and discussion}

Results of the compressive strength testing are shown in Table 5, ranked in descending

\footnotetext{
${ }^{5} \mathrm{SF}-\mathrm{W}-\mathrm{IM}=$ silica fume based activating solution/Wateree fly ash/Inside the molds

${ }^{6} \mathrm{SF}-\mathrm{W}-\mathrm{OM}=$ silica fume based activating solution /Wateree fly ash/Outside the molds

${ }^{7} \mathrm{SS}-\mathrm{W}-\mathrm{OM}=$ sodium silicate based activating solution /Wateree fly ash/Outside the molds

${ }^{8}$ SF-B-IM= silica fume based activating solution /Belws Creek fly ash/Inside the molds

${ }^{9}$ SS-W-IM= sodium silicate based activating solution /Wateree fly ash/Inside the molds

${ }^{10} \mathrm{SS}-\mathrm{B}-\mathrm{OM}=$ sodium silicate based activating solution /Belws Creek fly ash/Outside the molds
} 
211 performed in the molds. The compressive strength results for the silica fume/Wateree Station/in

212 molds combination were quite repeatable, with a difference of 2.1 MPa (351 psi) between the

213 highest and lowest results (within approximately $2 \%$ of the average result). To enable

214 comparisons between the different specimens, the highest compressive strength result [106.0

215 MPa (15,380 psi)] was chosen as a reference. Other results are reported as a percent deviation

216 from that baseline in the far right column of Table 5. A discussion of the effect of the type of

217 activating solution, the curing condition, and the fly ash source, is provided below.

Table 5: Experimental results

\begin{tabular}{|c|c|c|c|c|c|c|}
\hline $\begin{array}{l}\text { Specimen } \\
\text { type }\end{array}$ & $\begin{array}{c}\text { Activating } \\
\text { solution }\end{array}$ & $\begin{array}{l}\text { Fly ash } \\
\text { source }\end{array}$ & $\begin{array}{l}\text { Curing } \\
\text { condition }\end{array}$ & $\begin{array}{c}\text { Average* } \\
\text { compressive } \\
\text { strength at } 7 \text { days, } \\
\text { MPa (psi) }\end{array}$ & $\begin{array}{l}\text { Standard } \\
\text { deviation, } \\
\text { MPa (psi) }\end{array}$ & $\begin{array}{l}\text { Deviation } \\
\text { below } \\
\text { reference } \\
\text { (\%) }\end{array}$ \\
\hline SF-W-IM-1 & Silica fume & $\begin{array}{l}\text { Wateree } \\
\text { Station }\end{array}$ & $\begin{array}{l}\text { Inside the } \\
\text { molds }\end{array}$ & $106.0(15,380)$ & $4.0(580)$ & 0.0 \\
\hline SF-W-IM-2 & Silica fume & $\begin{array}{l}\text { Wateree } \\
\text { Station }\end{array}$ & $\begin{array}{c}\text { Inside the } \\
\text { molds }\end{array}$ & $105.5(15,300)$ & $4.4(635)$ & 0.1 \\
\hline SF-W-IM-3 & Silica fume & $\begin{array}{l}\text { Wateree } \\
\text { Station }\end{array}$ & $\begin{array}{l}\text { Inside the } \\
\text { molds }\end{array}$ & $103.8(15,050)$ & $2.4(350)$ & 0.1 \\
\hline SF-W-OM & Silica fume & $\begin{array}{l}\text { Wateree } \\
\text { Station }\end{array}$ & $\begin{array}{l}\text { Outside } \\
\text { the molds }\end{array}$ & $93.8(13,600)$ & $2.8(410)$ & 12 \\
\hline $\begin{array}{c}\text { SS-W-OM- } \\
1\end{array}$ & $\begin{array}{l}\text { Sodium } \\
\text { silicate }\end{array}$ & $\begin{array}{l}\text { Wateree } \\
\text { Station }\end{array}$ & $\begin{array}{l}\text { Outside } \\
\text { the molds }\end{array}$ & $60.7(8,800)$ & $2.6(380)$ & 43 \\
\hline $\begin{array}{c}\text { SS-W-OM- } \\
2\end{array}$ & $\begin{array}{l}\text { Sodium } \\
\text { silicate }\end{array}$ & $\begin{array}{l}\text { Wateree } \\
\text { Station }\end{array}$ & $\begin{array}{l}\text { Outside } \\
\text { the molds }\end{array}$ & $59.5(8,630)$ & $2.9(425)$ & 44 \\
\hline $\begin{array}{c}\text { SS-W-OM- } \\
3^{* *}\end{array}$ & $\begin{array}{l}\text { Sodium } \\
\text { silicate }\end{array}$ & $\begin{array}{l}\text { Wateree } \\
\text { Station }\end{array}$ & $\begin{array}{l}\text { Outside } \\
\text { the molds }\end{array}$ & $56.7(8,210)$ & $1.9(280)$ & 47 \\
\hline SF-B-IM-1 & Silica fume & $\begin{array}{c}\text { Belews } \\
\text { Creek }\end{array}$ & $\begin{array}{l}\text { Inside the } \\
\text { molds }\end{array}$ & $43.8(6,350)$ & $1.9(285)$ & 59 \\
\hline SS-W-IM-1 & $\begin{array}{l}\begin{array}{l}\text { Sodium } \\
\text { silicate }\end{array} \\
\end{array}$ & $\begin{array}{l}\text { Wateree } \\
\text { Station }\end{array}$ & $\begin{array}{l}\text { Inside the } \\
\text { molds }\end{array}$ & $38.5(5,580)$ & $2.6(380)$ & 64 \\
\hline SS-B-OM & $\begin{array}{l}\text { Sodium } \\
\text { silicate }\end{array}$ & $\begin{array}{l}\text { Belws } \\
\text { Creek }\end{array}$ & $\begin{array}{l}\text { Outside } \\
\text { the molds }\end{array}$ & $15.2(2,200)$ & $1.4(210)$ & 86 \\
\hline
\end{tabular}

*average of four specimens

**Mixture No. 3 (Table 3)

Note: Shaded cells indicate replicate specimens

$\mathrm{SF}=$ silica fume based activating solution

$\mathrm{SS}=$ sodium silicate based activating solution

$\mathrm{W}=$ Wateree fly ash

$\mathrm{B}=$ Belews Creek fly ash

$\mathrm{IM}=$ cured inside the molds

$\mathrm{OM}=$ cured outside the molds 


\subsection{Effect of activating solution type}

The effect of different activating solution types is apparent by comparing SF-W-IM-1,

230 (silica fume based activating solution) 106.0 MPa [15,380 psi]); and SS-W-IM-1 (sodium silicate

231 based activating solution, $38.5 \mathrm{MPa}$ [5,580 psi]) in Table 5. The results are shown graphically in

232 Figure 1. The comparison shows that the compressive strength is 64\% lower when sodium

233 silicate was used in place of silica fume in the activating solution. This is attributed to the fact

234 that geopolymer framework in fly ash-based geopolymers consists of bonds between oxygen and

235 silica; oxygen, silica, alumina; and oxygen, silica, alumina, and iron. The availability of readily

236 available silica to form the geopolymer chains is necessary for strong bonds within the polymer

237 chains. The total weight of $\mathrm{Si} / \mathrm{Na}$ ratio of FGC-silica fume is 52\%, while the ratio for FGC-

238 sodium silicate is $43 \%$. This difference in the $\mathrm{Si} / \mathrm{Na}$ weight ratio may contribute to the

239 compressive strength. In addition, the total weight ratios of $\mathrm{Na} / \mathrm{H}_{2} \mathrm{O}$ of FGC-silica fume and

240 FGC-sodium silicate are $21 \%$, and $42 \%$ respectively. In conclusion, the increase in the $\mathrm{Si} / \mathrm{Na}$

241 ratio and the reduction in the $\mathrm{Na} / \mathrm{H}_{2} \mathrm{O}$ ratio may improve the compressive strength of fly ash-

242 based geopolymer concrete. As shown in Table 3, water/binder ratio are higher in the FGC-silica

243 fume than FGC-sodium silicate, which leads to conclude that the water/binder ratio difference

244 does not explain the reason of high compressive strength in the FGC-silica fume samples. In Mix

2453 (SS-W-OM-3), which is used to identify effect of aggregate on the compressive strength, as

246 shown in Table 3, the course/fine aggregate in the FGC-sodium silicate was changed to 1:1 to

247 investigate effect of gravel ratio. The difference in compressive strength of specimens cast using

248 Mix 2 (SS-W-OM-1) and Mix 3 (SS-W-OM-3) is approximately 7\% which shows that no

249 significant difference was observed when the aggregate ratio was modified. 


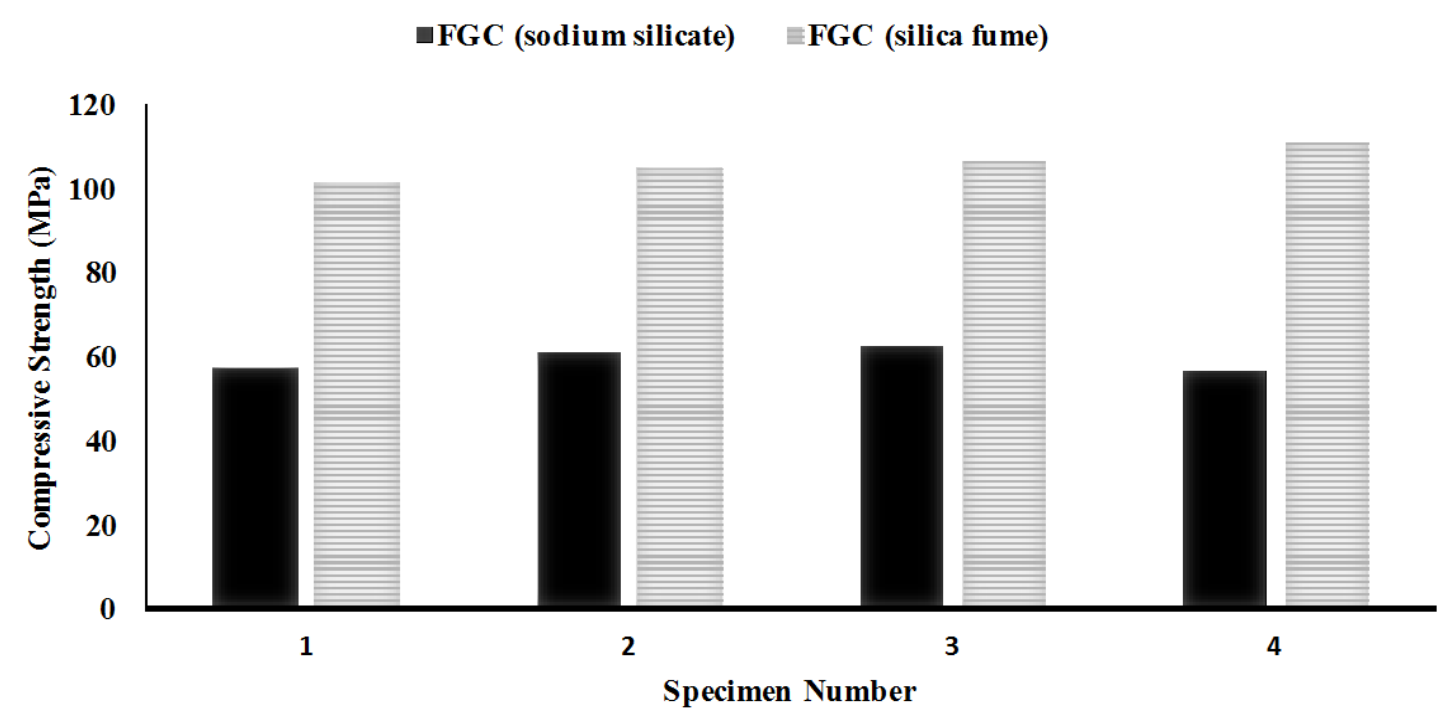

Fig. 1 Effect of activating solution type (comparing SF-W-IM-1 to specimen SS-W-IM of Table 5), $1 \mathrm{MPa}=145.038 \mathrm{psi}$

\subsection{Effect of curing condition}

256 different curing conditions on FGC-silica fume is apparent by comparing SF-W-IM-1 (cured in 257 molds; 106.0 MPa [15,380 psi]) and SF-W-OM (cured outside of molds; 93.8 MPa [13,600 psi]) 258 in Table 5. The results are shown graphically in Figure 2. The comparison shows that the 259 compressive strength is $12 \%$ lower when the specimens were cured outside the molds. An 260 opposite trend was observed for the specimens of FGC-sodium silicate. By comparing SS-W-

261 OM-1 (cured outside of molds; $60.7 \mathrm{MPa}$ [8,800 psi]) and SS-W-IM-1 (cured in molds; 38.5 262 MPa [5,580 psi]) in Table 5 (shown graphically in Figure 3), it can be seen that curing in the 263 molds resulted in a 37\% reduction in compressive strength.

264 The reason for slight difference in the FGC-silica fume results is attributed to the high 265 rate of polymerization reaction; therefore, the compressive strength is only slightly affected 266 when specimens are cured outside the molds. For FGC-sodium silicate, the degree of 267 polymerization may be higher, and the significant difference in compressive strength may be 
268 attributed to an expansion which may produce micro-cracking if the sample is kept in a 269 constrained container. Further studies are recommended to aid in the explanation of differences 270 in compressive strength when curing conditions are changed.

271

272

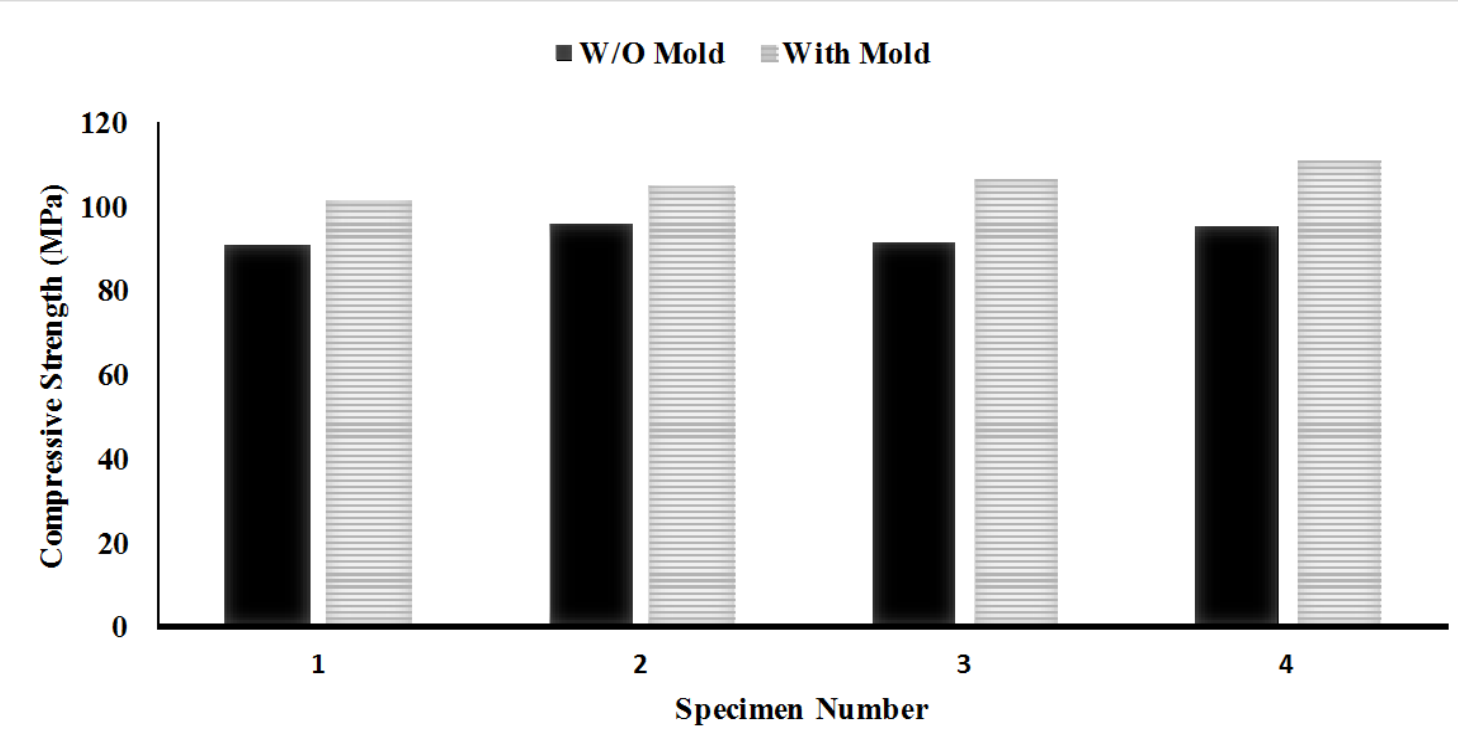

Fig. 2 Effect of curing condition on FGC-silica fume (comparing SF-W-IM-1 to SF-W-OM of Table 5), $1 \mathrm{MPa}=145.038 \mathrm{psi}$

Belews Creek $\equiv$ Wateree Station

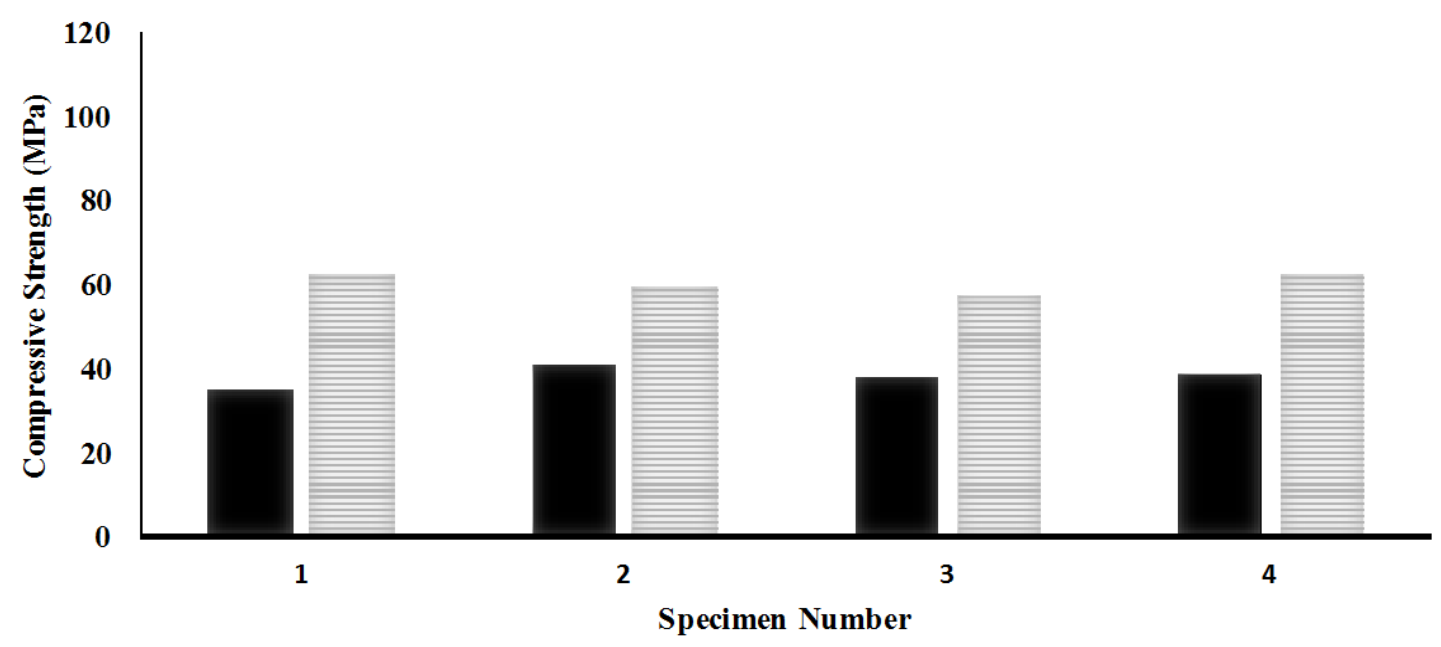

Fig. 3 Effect of curing on FGC-sodium silicate (comparing SS-W-IM-1 to SS-W-OM of Table 5), $1 \mathrm{MPa}=145.038 \mathrm{psi}$ 
The effect of different fly ash sources on the resulting compressive strength of FGC-silica

280 fume is apparent by comparing SF-W-IM-1 through SF-W-IM-3 (Wateree Station fly ash source;

281 average of all three specimens = 105.1 MPa [15,240 psi]) and SF-B-IM-1 (Belews Creek fly ash

282 source; 43.8 MPa [6,350 psi]) in Table 5. The comparison shows that the compressive strength

283 increased by 58\% when the Wateree Station fly ash source was utilized. This significant increase

284 in compressive strength associated with the Wateree Station fly ash source was not expected and

285 the reason for this dramatic increase is not entirely clear. It is noted that the Wateree Station

286 source was subjected to a carbon burn out process while the Belews Creek source was not. This

287 unexpected increase in compressive strength prompted further chemical and petrographic

288 analysis, SEM observations, as well as absorption and void space ASTM (642-06) testing, as

289 described further below. The results of the comparison of SF-W-IM and SF-B-IM are shown

290 graphically in Figure 4.

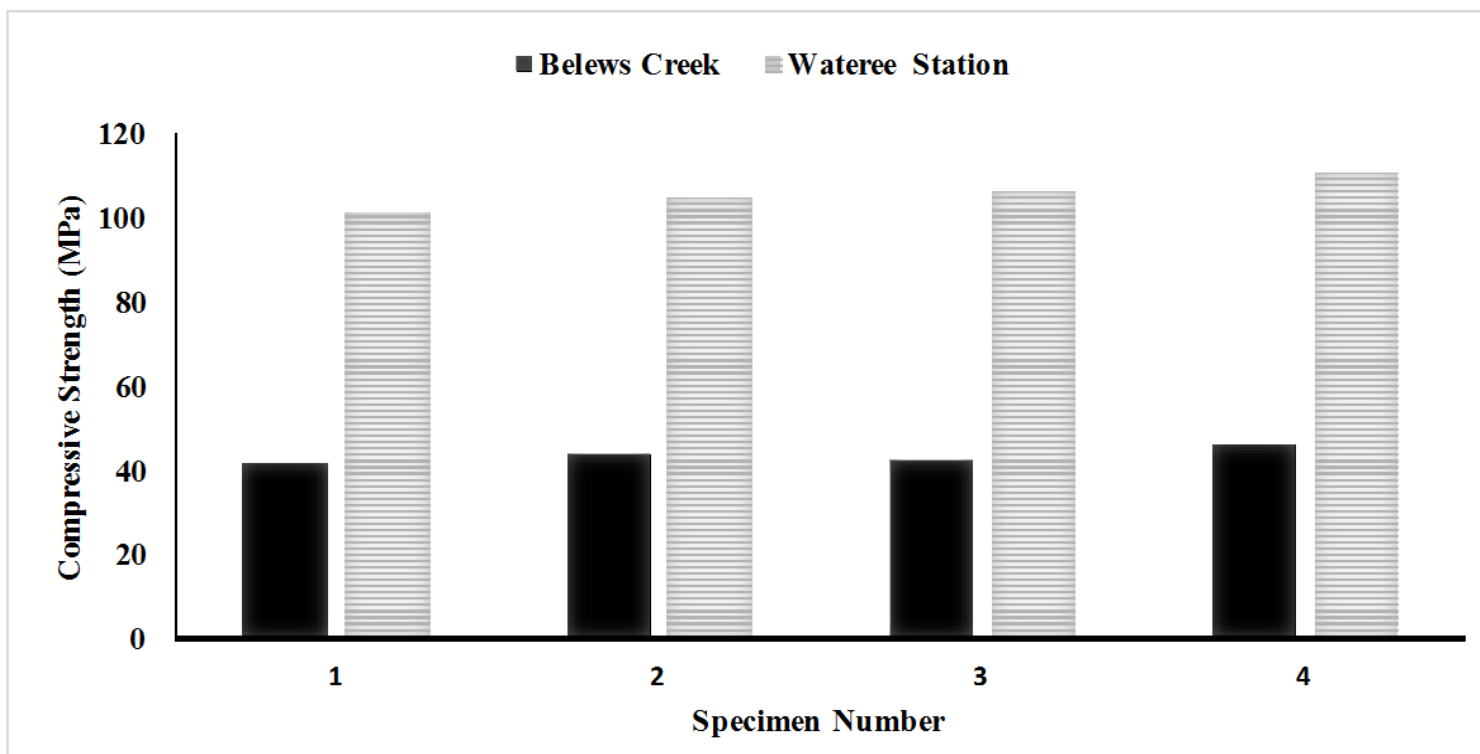




\subsubsection{X-Ray Florescence (XRF) and Thermal Gravimetric Analysis (TGA)}

The chemical and physical characteristics of FGC-silica fume made using different fly

297 ash sources, the Wateree Station fly ash (SF-W-IM-1, Table 5) and the Belews Creek Station fly

298 ash (SF-B-IM-1, Table 5), were further investigated in an attempt to understand the difference in 299 compressive strength.

300 The chemical differences between the two specimens (SF-W-IM-1 and SF-B-IM-1) were 301 investigated by conducting x-ray florescence (XRF) as shown in Table 6 using fused bead 302 analysis. In addition, thermal gravimetric analysis (TGA) was used to look at powdered paste 303 samples prepared using both fly ashes in combination with the entire binder system (rather than 304 just the fly ash powder component) to examine the total reaction products. The XRF analysis 305 method was used for chemical analysis of the fly ash, while the TGA method used coal analysis 306 for the fly ash to focus on the determination of carbon and sulfur.

307 The results of XRF showed that the binder system containing the Wateree Station fly ash 308 did have $4.58 \%$ more silica dioxide $\left(\mathrm{SiO}_{2}\right)$ and $2.54 \%$ more aluminum oxide $\left(\mathrm{Al}_{2} \mathrm{O}_{3}\right)$ per weight 309 of binder than the binder system containing the Belews Creek fly ash. The $\mathrm{SiO}_{2} / \mathrm{Al}_{2} \mathrm{O}_{3}$ ratios of 310 both fly ash sources were almost the same where the Wateree Station fly ash binder system had a 311 ratio of $2.19 \%$ while the Belews Creek binder system had a ratio of $2.22 \%$. This indicates that 312 the ratios were fairly consistent, but the Wateree fly ash binder system had more $\mathrm{SiO}_{2}$ and $\mathrm{Al}_{2} \mathrm{O}_{3}$ 313 to form reaction products when introduced to the sodium hydroxide $(\mathrm{NaOH})$ and silica fume 314 activator in the form of Si-O and Si-O-Al-O- polymer chains. The calcium oxide $(\mathrm{CaO})$ and 315 sulfur in the form of $\left(\mathrm{SO}_{3}\right)$ were also higher in the Belews Creek binder system, which are not 316 considered in the reaction products contributing to compressive strength and could be considered 317 as dilution products by reducing the total amount of $\mathrm{SiO}_{2}$ and $\mathrm{Al}_{2} \mathrm{O}_{3}$ available when compared to 
318 the Wateree fly ash. This is only a theory, but considering that there is less $\mathrm{SiO}_{2}$ and $\mathrm{Al}_{2} \mathrm{O}_{3}$ in the

319 Belews Creek ash to form reaction products, it could contribute to some of the lower 320 compressive strength results.

321 Both powder paste samples did show very high alkali levels with both showing levels at $3228.7 \%$, but this is expected due to the use of sodium hydroxide $(\mathrm{NaOH})$ as part of the activating 323 solution. However, the high alkali levels reported in the XRF analysis are important to mention 324 due to the potential of alkali silica reactivity when utilized in some concrete systems.

325 TGA was used to determine the differences in $\mathrm{SO}_{3}$ and carbon (C) content between the 326 two samples. In terms of dilution factors the results showed that the Wateree Station based 327 powdered paste had a higher content of both compounds, but the percentages of these 328 compounds in the systems are very small and probably have little to do with the compressive 329 strength differences when used in concrete. However, the higher carbon content in the Wateree 330 Station based paste is probably the reason for the darker color seen in both the paste and concrete 331 samples.

332 The concrete samples investigated were from two broken $75 \mathrm{~mm}$ x $150 \mathrm{~mm}$ (3 in. x 6 in.) 333 cylinders, as shown in Figure 5, that were previously tested for compressive strength. One was 334 from concrete made using the Wateree Station fly ash source which had a compressive strength 335 of about $106 \mathrm{MPa}(15,300 \mathrm{psi}), \mathrm{SF}-\mathrm{W}-\mathrm{IM}-1$, and the other from concrete made using the Belews 336 Creek fly ash source resulting in compressive strength of about $43 \mathrm{MPa}$ (6,350 psi), SF-B-IM. It 337 was observed that the paste fraction of the Wateree fly ash was darker in color. Both samples 338 were cut along the longitudinal axis and polished for petrographic analysis with three random 339 areas selected for microscopic examination as shown in Figure 6. 
Observations noted were that the coarse aggregate in the Belews Creek samples had

341 larger aggregate particles and may have been from a different aggregate source or may have been

342 blended in with the same aggregate source as the Wateree Station sample, but the differences in

343 the coarse aggregate did not appear to have contributed to the differences in the compressive

344 strength due to the sharp clean aggregate fractures along the failure planes of both samples.

345 The paste density appeared similar in both concretes and was noted as being very dense

346 when compared to conventional concretes, but the paste uniformity seemed to look better in the

347 higher strength concrete [SF-W-IM-1]. The paste contrast did look sharper and less muted in the

348 Wateree Station sample, which may suggest a higher percentage of glass dissolution that took

349 place during the chemical process between the fly ash and the activating solution.

350 The overall hardened air volume and void size looks slightly larger in the Belews Creek

351 sample, but both concrete samples had very low air contents, in the range of $1 \%$ or less. The

352 differences in air content in combination with differences in glass dissolution and chemical

353 dilution factors of non-reactive materials in the fly ashes may have caused the differences in

354 compressive strength. However, additional research is warranted to better understand the reasons

355 of the compressive strength differences. 
Table 6: XRF chemical analysis of paste

\begin{tabular}{|l|c|c|}
\hline Compound & $\begin{array}{c}\text { Wateree Station (SF-W-IM-1) Sample } \\
\text { wt. } \%\end{array}$ & $\begin{array}{c}\text { Belews Creek Station SF-B-IM-1 (Sample) } \\
\text { wt.\% }\end{array}$ \\
\hline Silicon Dioxide & 55.4 & 50.9 \\
\hline Aluminum Oxide & 25.4 & 22.9 \\
\hline Iron Oxide & 4.6 & 7.7 \\
\hline Calcium Oxide & 0.6 & 3.9 \\
\hline Magnesium Oxide & 0.6 & 1.0 \\
\hline Sulfur Trioxide & 0.1 & 0.6 \\
\hline Sodium Dioxide & 7.4 & 7.0 \\
\hline Potassium Oxide & 2.1 & 2.7 \\
\hline Total Alkali & 8.7 & 8.7 \\
\hline Phosphate (P205) & 0.1 & 0.3 \\
\hline Titanium Dioxide & 1.1 & 1.0 \\
\hline Manganese Oxide & 0.1 & 0.1 \\
\hline
\end{tabular}

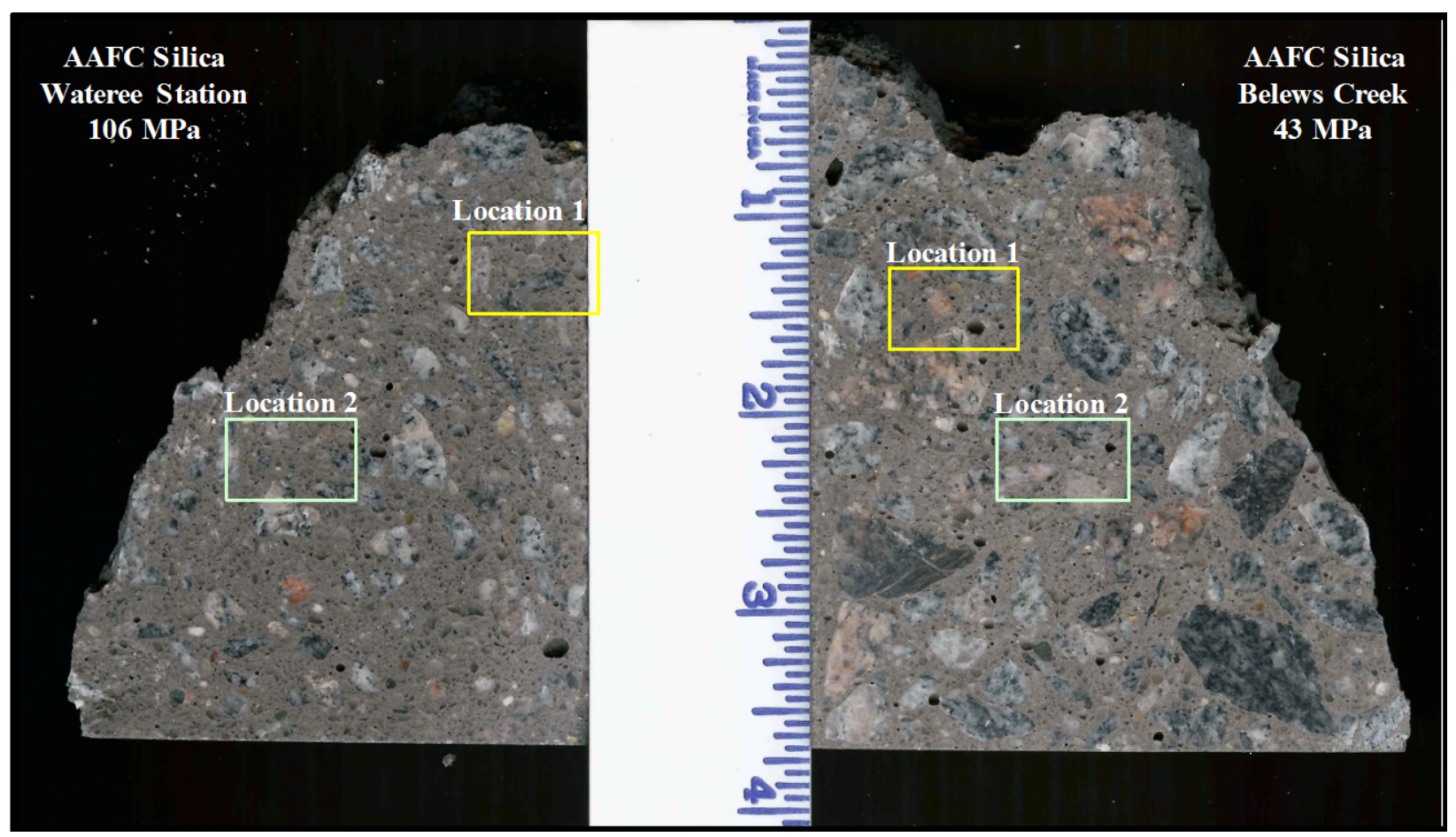

Fig. 5 Prepared vertical test sections of FGC-silica fume, $1 \mathrm{MPa}=145.038 \mathrm{psi}$ 
361
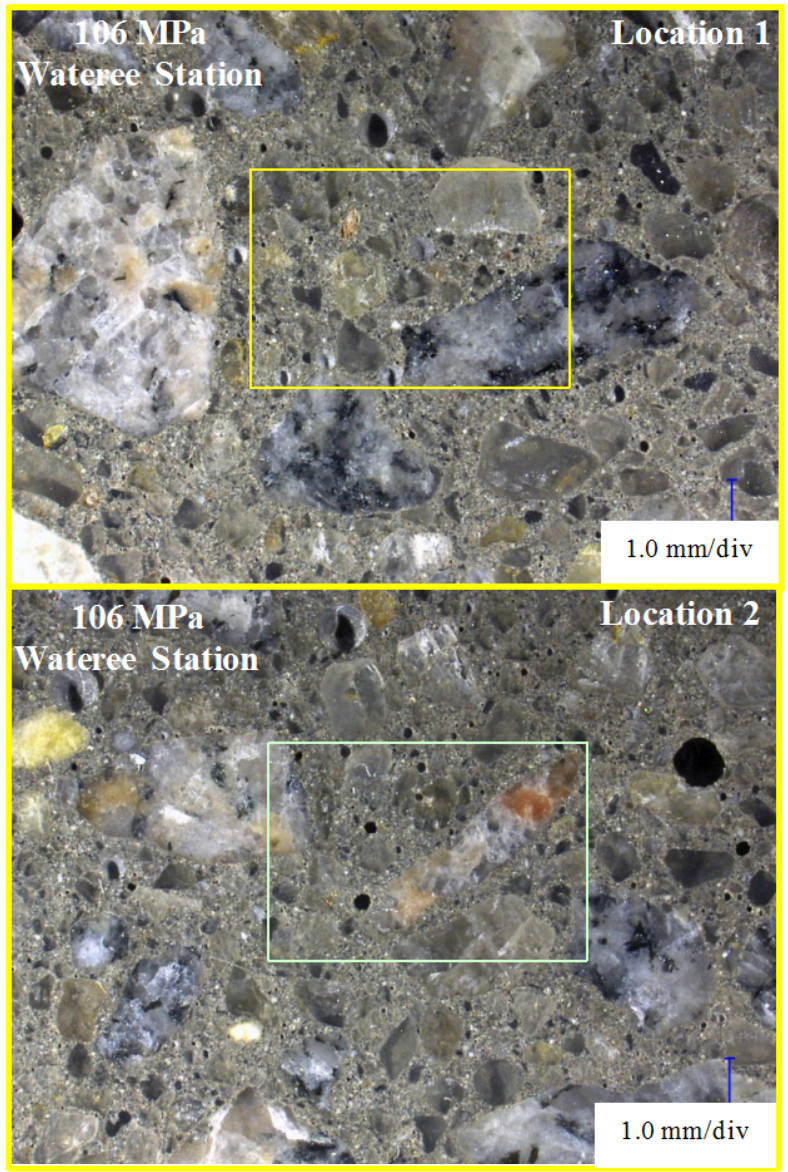
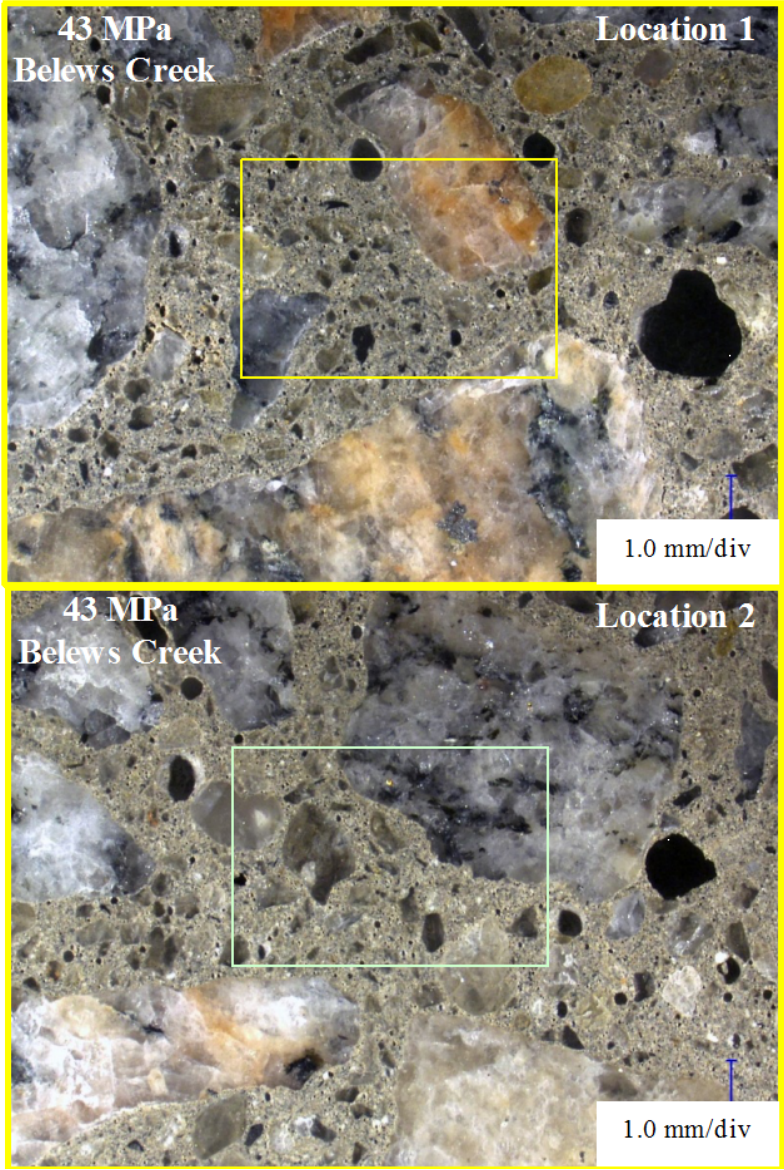

Fig. 6 Micrograph images of FGC-silica fume, 1MPa = 145.038 psi

\subsubsection{Scanning Electron Microscopy (SEM) observations}

To investigate the microstructure of FGC-silica fume and the differences when different

365 fly ash sources were used, two fly ash-based geopolymer pastes were prepared. The fly ash-

366 based geopolymer paste samples were cast at the same time and environment according to the

367 procedure explained in the materials section above. The activating solution, a combination of

368 silica fume, sodium hydroxide and water, was prepared as described in the material section. It

369 was then mixed with one of the two different fly ash sources (Wateree Station or Belews Creek).

370 The two paste samples were kept for two days at ambient temperature, and were then heated for

371 two days at $75^{\circ} \mathrm{C}\left(167^{\circ} \mathrm{F}\right)$. The SEM observations were conducted in the microscopy center at the 
372 University of South Carolina. The age of the fly ash-based geopolymer paste samples was 7 days

373 when the SEM observations were conducted. Figure 7.A shows that the Wateree Station fly ash

374 paste is completely dissolved and reacted with the activating solution. Comparing with the

375 Belews Creek fly ash paste sample shown in Figure 7.B, the Wateree sample appears free of 376 voids and is relatively dense. On the other hand, for fly ash-based geopolymer paste with Belews

377 Creek fly ash, Figure 7.D shows that there is some fly ash that has not yet reacted compared with 378 the Wateree sample shown in Figure 7.C. The unreacted fly ash in the Belews Creek sample may 379 have resulted from two reasons: 1) Particle size distribution, shown in Figure 8, where Wateree 380 Station fly ash is finer than Belews Creek fly ash. The average particles size for Wateree and 381 Belews Creek fly ash is 16.2 and $20.3 \mu \mathrm{m}$ respectively with difference in value of $26 \%$. This 382 leads to a higher polymerization rate due to large surface area; 2) Some of the Belews Creek fly 383 ash particles were isolated from the activating solution (within cenospheres), which may delay 384 the polymerization process. Therefore, it can be deduced that the fly ash source not only affects 385 the reaction between the activating solution and fly ash, which may reduce the compressive 386 strength of FGC, it may also affect the durability of resulting FGC-silica fume concrete due to 387 high apparent voids. As shown in the figures, there is a significant difference in the number of 388 voids when the fly ash source was changed. 


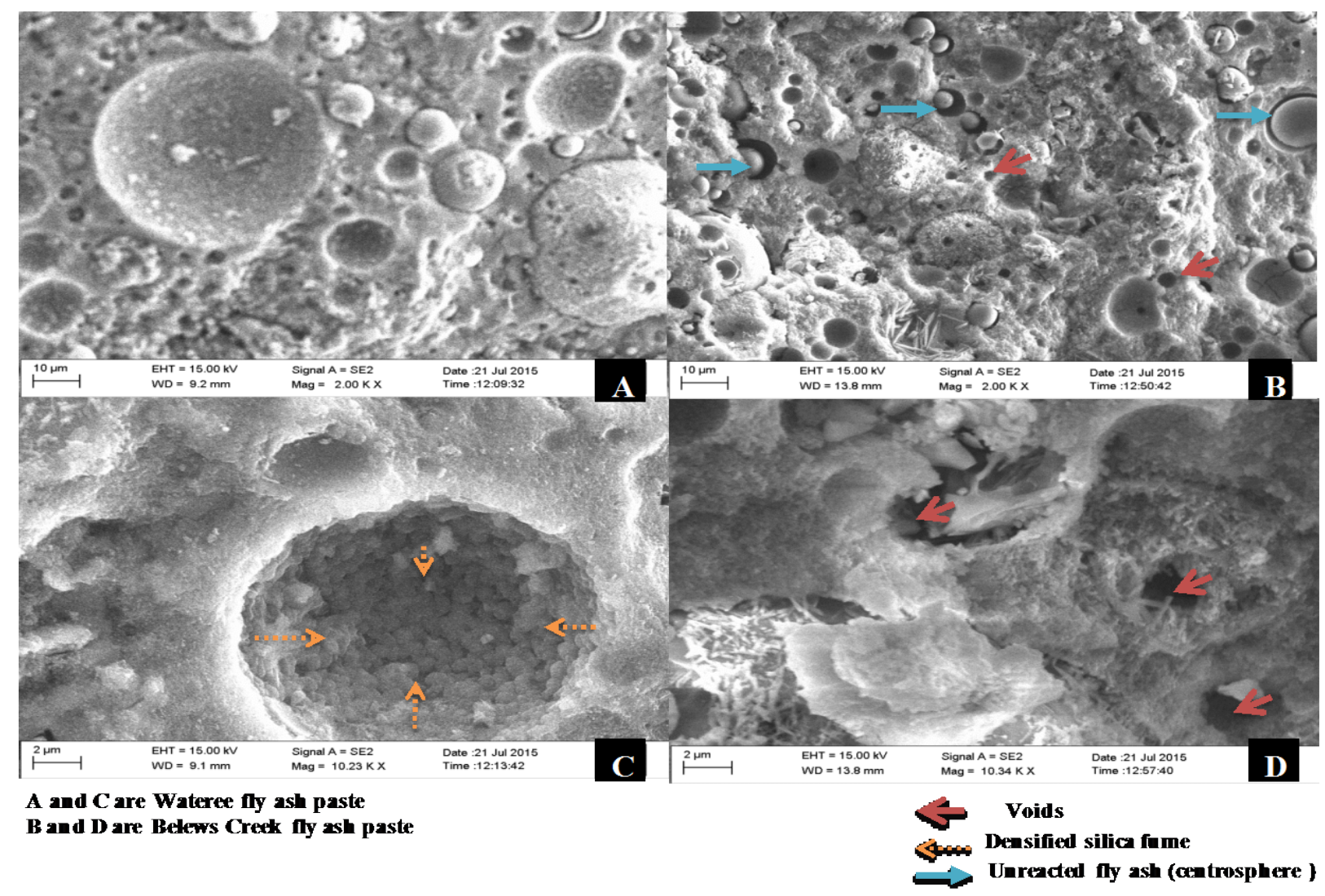

Fig. 7 SEM observation: A) Wateree fly ash paste, B) Belews Creek fly ash paste, C) Wateree fly ash paste at higher magnification, and D) Belews Creek fly ash paste at higher magnification

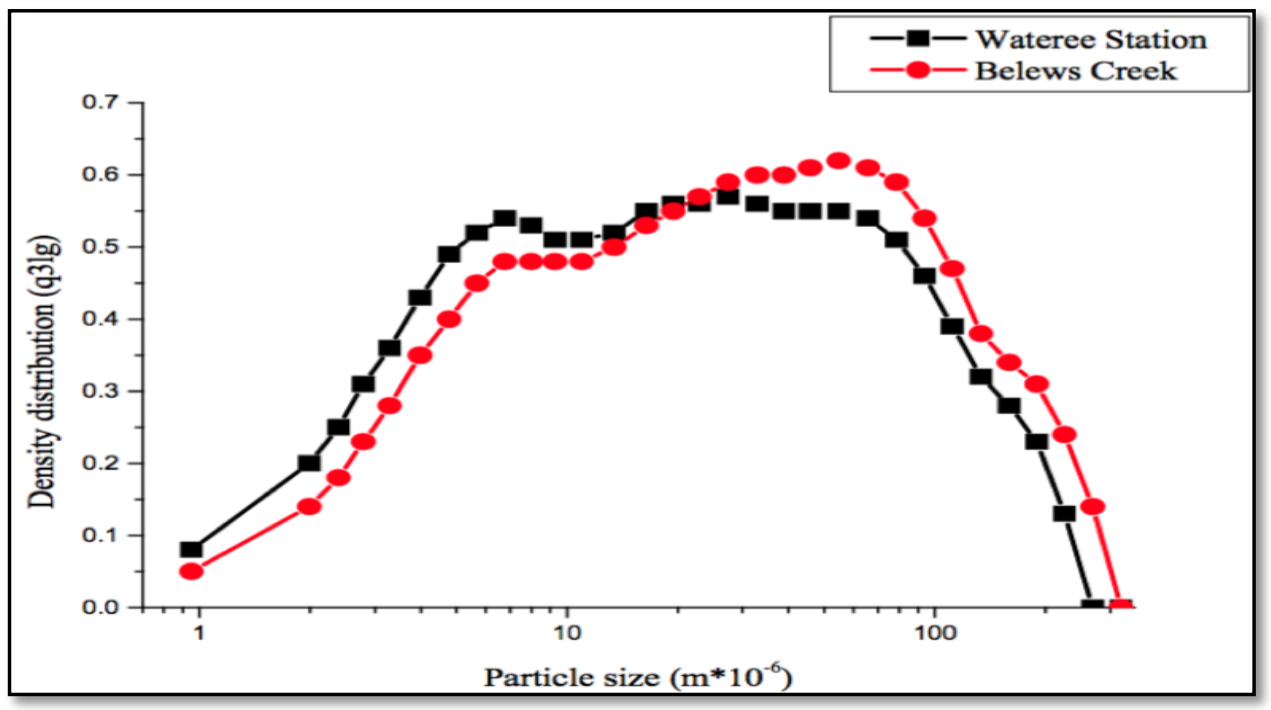

Fig. 8 Fly ash particle size distribution 


\subsubsection{Absorption and void space results (ASTM C 642-06)}

The absorption and void space of FGC specimens fabricated with two different activating

396 solutions (silica fume/sodium hydroxide or sodium silicate/sodium hydroxide) and two different

397 fly ash sources, Wateree Station and Belews Creek, were investigated. New samples were cast

398 using combinations of the two factors as shown in Table 7. The samples were cast and cured

399 following the same procedures described previously. Four samples were tested for each

400 specimen. The age of the concrete was 7 days in all cases. The main purpose of this test was to

401 investigate the effect of different fly ash sources on the absorption, density and voids of FGC-

402 silica fume and FGC-sodium silicate. The relationship between the compressive strength and the 403 total permeable voids space (ASTM C 642-06) was also studied.

404 As shown in Table 7 and Figure 9, specimens with Belews Creek fly ash had higher 405 absorption and volume of permeable pore space in both FGC activating solutions. FGC with 406 Wateree Station fly ash has a lower volume of permeable pore space in comparison with results 407 of conventional concrete found in the literature [27]. Figure 10 shows a clear correlation between 408 volume of permeable pore space and compressive strength. Considering the same activating 409 solution, when the rate of absorption and volume of permeable pore space increase the associated 410 compressive strength decreases. In addition, the bulk and apparent density increased when

411 Wateree Station fly ash was used regardless of the activating solution type. This test shows that 412 FGC with Wateree Station fly ash is denser than FGC with Belews Creek fly ash, i.e. fewer 413 and/or smaller voids exists in the Wateree Station fly ash FGC. This observation is in agreement 414 with, and confirms, the reported SEM observations. 
Table 7: Sample description and ASTM 642-06 results

\begin{tabular}{|c|c|c|c|c|c|c|c|}
\hline $\begin{array}{c}\text { Specimen } \\
\text { type }\end{array}$ & $\begin{array}{c}\text { Activating } \\
\text { solution }\end{array}$ & $\begin{array}{c}\text { Fly ash } \\
\text { source }\end{array}$ & $\begin{array}{c}\text { Bulk } \\
\text { density }^{*} \\
(\mathrm{dry}), \\
\mathrm{g} / \mathrm{cm}^{3} \\
\left(\mathrm{lb} / \mathrm{ft}^{3}\right)\end{array}$ & $\begin{array}{c}\text { Apparent } \\
\text { density } \\
\mathrm{g}^{*} \mathrm{~cm}^{3} \\
\left(\mathrm{lb} / \mathrm{ft}^{3}\right)\end{array}$ & $\begin{array}{c}\text { Absorption } \\
\text { after } \\
\text { immersion*, } \\
\%\end{array}$ & $\begin{array}{c}\text { Volume of } \\
\text { permeable } \\
\text { pore } \\
\text { space*, \% }\end{array}$ & $\begin{array}{c}\text { Compressive } \\
\text { strength*, }^{*} \\
\text { MPa (psi) }\end{array}$ \\
\hline $\begin{array}{c}\text { SF-W- } \\
\text { IM-4 }\end{array}$ & $\begin{array}{c}\text { Silica } \\
\text { fume }\end{array}$ & $\begin{array}{c}\text { Wateree } \\
\text { Station }\end{array}$ & $\begin{array}{c}2.19 \\
(137)\end{array}$ & $2.48(155)$ & 5.0 & 11.7 & $\begin{array}{c}106.1 \\
(15,390)\end{array}$ \\
\hline $\begin{array}{c}\text { SF-B-IM- } \\
2\end{array}$ & $\begin{array}{c}\text { Silica } \\
\text { fume }\end{array}$ & $\begin{array}{c}\text { Belews } \\
\text { Creek }\end{array}$ & $\begin{array}{c}2.10 \\
(131)\end{array}$ & $2.46(153)$ & 6.1 & 14.6 & $43.9(6,360)$ \\
\hline $\begin{array}{c}\text { SS-W- } \\
\text { IM-2 }\end{array}$ & $\begin{array}{c}\text { Sodium } \\
\text { silicate }\end{array}$ & $\begin{array}{c}\text { Wateree } \\
\text { Station }\end{array}$ & $\begin{array}{c}2.23 \\
(139)\end{array}$ & $2.49(155)$ & 4.3 & 10.0 & $60.6(8,790)$ \\
\hline SS-B-IM & $\begin{array}{c}\text { Sodium } \\
\text { silicate }\end{array}$ & $\begin{array}{c}\text { Belews } \\
\text { Creek }\end{array}$ & $\begin{array}{c}2.16 \\
(135)\end{array}$ & $2.46(154)$ & 5.3 & 12.2 & $17.2(2,500)$ \\
\hline
\end{tabular}

418

$\diamond$ FGC-sodium silicate, Wateree Station FGC-sodium silicate, Belews Creek

$\Delta$ FGC-silica fume, Wateree Station $\times$ FGC-silica fume, Belews Creek

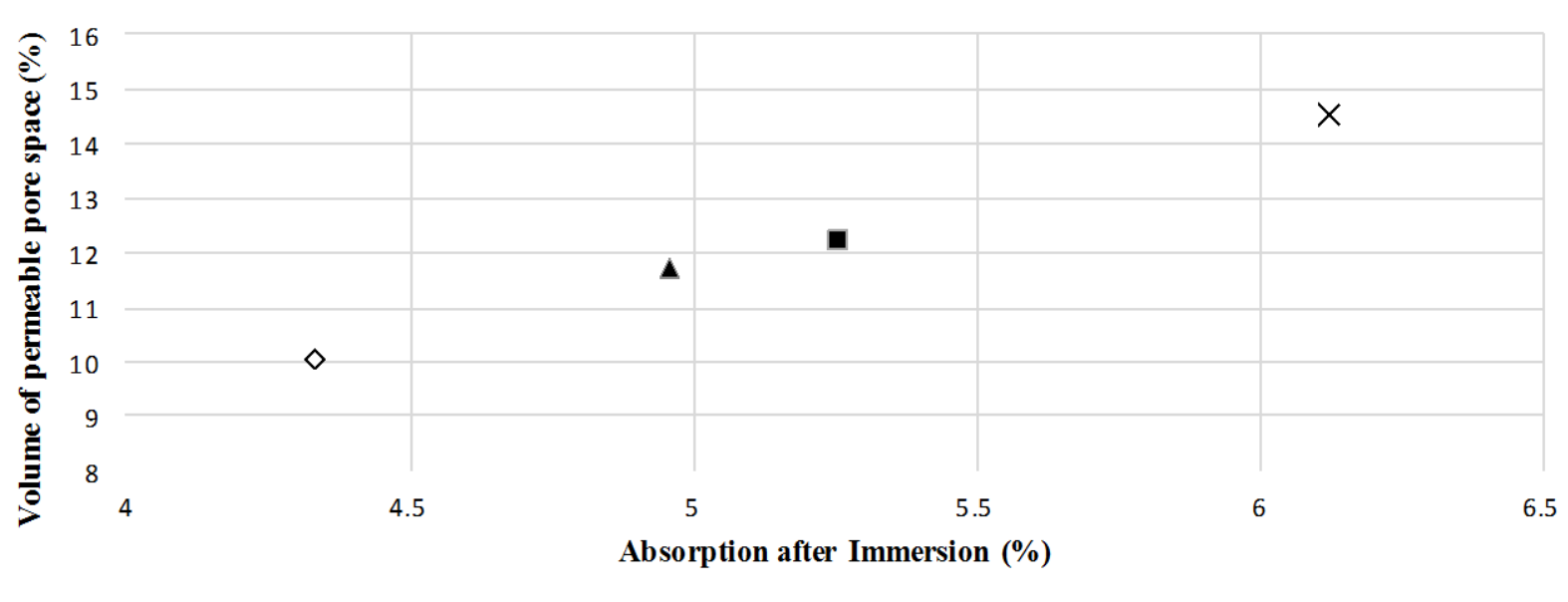

Fig. 9 Volume of permeable pore space and absorption after immersion 


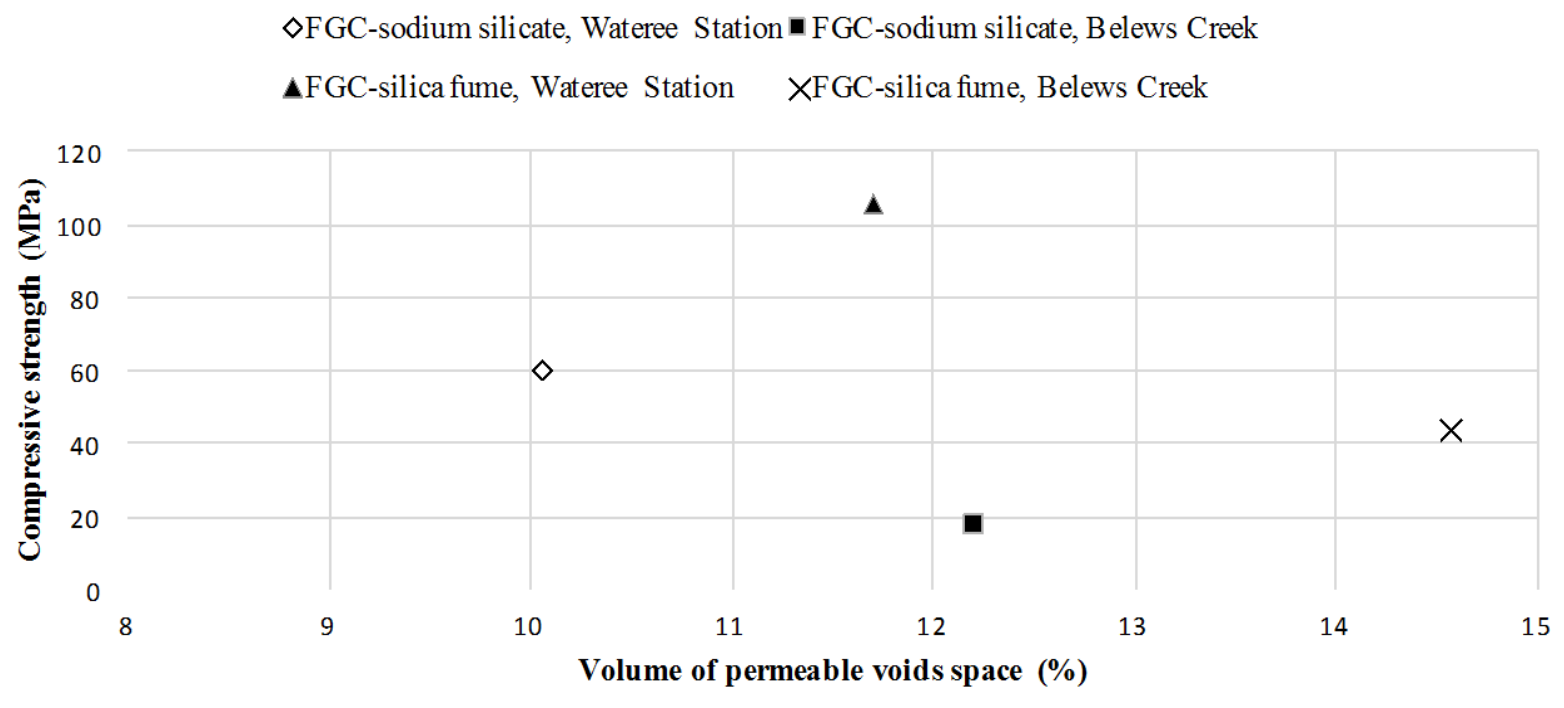

Fig. 10 Volume of permeable voids space and compressive strength correlation,

$1 \mathrm{MPa}=145.038 \mathrm{psi}$

\section{4. Conclusions}

1. A significantly high early compressive strength was achieved (around $105.1 \mathrm{MPa}$ [15,240 psi]) with fly ash-based geopolymer concrete (FGC) using Type F fly ash and silica fume activating solution. The cementitious materials content was $100 \%$ fly ash (no Portland cement). This shows the promise of developing and using this alternative concrete to replace ordinary Portland cement concrete. However, the use of heat during the curing period may, for the near future, limit applications of this material to precast concrete. strength values as compared to similar specimens cast using sodium silicate based activating solution.

3. Curing conditions (cured inside or outside the molds) did not have a significant effect on the compressive strength when silica fume was used in the activating solution. For 
The opposite trend was observed when sodium silicate was used in the activating solution, where significantly higher compressive strength values were achieved in specimens cured outside the molds.

4. The use of different fly ash sources (Wateree Station fly ash versus Belews Creek fly ash) had a significant impact on the compressive strength of fly ash-based geopolymer concrete (FGC) due to particle size distribution difference and isolated fly ash particles (entrapped within cenospheres), which led to significant differences in the microstructure as well.

5. Samples fabricated with the Wateree Station fly ash source resulted in less absorption after immersion and volume of permeable voids space than samples fabricated with the Belews Creek fly ash source.

It is noted that this study did not investigate potential concrete material degradation mechanisms associated with the use of external heat curing, such as delayed ettringite formation 451 (DEF), or the high alkalinity of the concrete, such as alkali-silica reaction (ASR). However, DEF 452 in FGC with fly ash Type F is less likely to occur because the calcium oxide component is low 453 (around $4 \%$ of the total material). If fly ash Type C is used, DEF may affect the sustainability of 454 the concrete. The high alkalinity of FGC promotes ASR degradation; therefore, only aggregates 455 known to have low propensity for reactivity should be considered for use in FGC.

\section{5. Acknowledgement}

457 This research is based upon work supported partially by the U.S. Department of Energy Office of 458 Science, Office of Basic Energy Sciences and Office of Biological and Environmental Research 459 under Award Number DE-SC-00012530. 


\section{References}

461 [1] A. Hasanbeigi, C. Menke, L. Price, The CO2 abatement cost curve for the Thailand 462 cement industry, J. Clean. Prod. 18 (2010) 1509-1518.

[2] C. Chen, G. Habert, Y. Bouzidi, A. Jullien, Environmental impact of cement production: detail of the different processes and cement plant variability evaluation, J. Clean. Prod. 18 (2010) 478-485.

D.L.Y. Kong, J.G. Sanjayan, Damage behavior of geopolymer composites exposed to elevated temperatures, Cem. Concr. Compos. 30 (2008) 986-991.

[4] J.S.J. Van Deventer, J.L. Provis, P. Duxson, Technical and commercial progress in the 469 adoption of geopolymer cement, Miner. Eng. 29 (2012) 89-104.

470 [5] P. Duxson, A. Fernández-Jiménez, J.L. Provis, G.C. Lukey, A. Palomo, J.S.J. Deventer, 471 Geopolymer technology: the current state of the art, J. Mater. Sci. 42 (2006) 2917-2933.

[6] E.I. Diaz, E.N. Allouche, S. Eklund, Factors affecting the suitability of fly ash as source 473 material for geopolymers, Fuel. 89 (2010) 992-996.

474 [7] C.K. Yip, G.C. Lukey, J.L. Provis, J.S.J. van Deventer, Effect of calcium silicate sources 475 on geopolymerisation, Cem. Concr. Res. 38 (2008) 554-564. based geopolymer concrete, ACI Mater. J. 101 (2004) 467-472. 
478 [9] S.E. Wallah, Drying Shrinkage of Heat-Cured Fly Ash-Based Geopolymer Concrete,

$479 \quad$ Mod. Appl. Sci. 3 (2000) 14-21.

480 [10] D.M.J. Sumajouw, D. Hardjito, S.E. Wallah, B. V. Rangan, Fly ash-based geopolymer

481 concrete: Study of slender reinforced columns, J. Mater. Sci. 42 (2007) 3124-3130.

482 [11] V. Rangan, Fly Ash-Based Geopolymer Concrete, Int. Work. Geopolymer Cem. Concr. $483 \quad$ (2010).

484 [12] S.E. Wallah, Creep Behaviour of Fly Ash-Based Geopolymer Concrete, Civ. Eng. $485 \quad$ Dimens. 12 (2011) 73-78.

486 [13] P. Nath, P.K. Sarker, V.B. Rangan, Early Age Properties of Low-calcium Fly Ash 487

[14] T. Bakharev, Durability of geopolymer materials in sodium and magnesium sulfate solutions, Cem. Concr. Res. 35 (2005) 1233-1246.

[15] S. Hu, H. Wang, G. Zhang, Q. Ding, Bonding and abrasion resistance of geopolymeric 491

[16] B.C. McLellan, R.P. Williams, J. Lay, A. van Riessen, G.D. Corder, Costs and carbon repair material made with steel slag, Cem. Concr. Compos. 30 (2008) 239-244.

[17] M. Olivia, H. Nikraz, Properties of fly ash geopolymer concrete designed by Taguchi 496 method, Mater. Des. 36 (2012) 191-198. 
[18] N. A. Lloyd, B. V. Rangan, Geopolymer concrete with fly ash, Second Int. Conf. Sustain. Constr. Mater. Technol. 3 (2010) 1493-1504.

[19] Z. Pan, J.G. Sanjayan, Factors influencing softening temperature and hot-strength of geopolymers, Cem. Concr. Compos. 34 (2012) 261-264.

[20] N. Jambunathan, J.G. Sanjayan, Z. Pan, G. Li, Y. Liu, A.H. Korayem, et al., The role of alumina on performance of alkali-activated slag paste exposed to $50^{\circ} \mathrm{C}$, Cem. Concr. Res. 54 (2013) 143-150.

[21] D. Hester, C. McNally, M. Richardson, A study of the influence of slag alkali level on the alkali-silica reactivity of slag concrete, Constr. Build. Mater. 19 (2005) 661-665.

[22] B. Tempest, O. Sanusi, J. Gergely, V. Ogunro, D. Weggel, Compressive Strength and Embodied Energy Optimization of Fly Ash Based Geopolymer Concrete, World. (2009) $1-17$.

[23] F. Goodarzi, Characteristics and composition of fly ash from Canadian coal-fired power plants, Fuel. 85 (2006) 1418-1427.

[24] O. Mass, S. Mass, A. Immersion, A. Boiling, I.A. Mass, Standard Test Method for Density , Absorption , and Voids in Hardened Concrete 1, (2008) 11-13.

[25] American Concrete Institute Committee 211, Standard practice for selecting proportions for normal, heavyweight, and mass concrete [211.1-91: Standard Practice for Selecting Proportions for Normal, Heavyweight, and Mass Concrete (Reapproved 2009)], American Concrete Institute, 1997. 
517 [26] R.K. Roy, Design of Experiments Using The Taguchi Approach: 16 Steps to Product and Process Improvement, (2001) 560.

519 [27] J. Castro, R. Spragg, P. Compare, W. J. Weiss, Portland cement concrete pavement 520 per`meability pefromence, Technical Summary, Technology Transfer and Project 521 Implementation Information, (2010), SPR-3093. 